\title{
Hot water treatment effect in the elephant grass ashes calcinated at different temperatures
}

\section{Efeito do tratamento de água quente nas cinzas de capim elefante calcinadas em diferentes temperaturas}

\author{
Erika Yukari Nakanishi ${ }^{1}$, Valdemir dos Santos ${ }^{1}$, Matheus Roberto Cabral ${ }^{1}$, \\ Sérgio Francisco Santos ${ }^{2}$, Michelle Santos Rodrigues ${ }^{3}$, Moisés Frías ${ }^{4}$, \\ Holmer Savastano Junior ${ }^{1}$
}

\author{
${ }^{1}$ University of São Paulo, Research Nucleus on Materials for Biosystems (BIOSMAT), Pirassununga, SP, Brazil \\ e-mail: tyou.eyuna@gmail.com \\ e-mail: valdemir@usp.br; matheusrc@usp.br; holmersj@usp.br \\ ${ }^{2}$ São Paulo State University, School of Engineering, Department of Materials and Technology, Guaratinguetá, SP, Brazil \\ e-mail: sergio.francisco-santos@unesp.br \\ ${ }^{3}$ São Paulo Faculty of Technology - Centro Paula Souza, São Paulo, SP, Brazil \\ e-mail: michatcsr@gmail.com \\ ${ }^{4}$ Eduardo Torroja Institute (IETcc-CSIC), Madrid, Madrid, Spain. \\ e-mail: mfrias@ietcc.csic.es
}

\begin{abstract}
In recent years, agro-industrial residues have focused attention in the scientific community as a new source of pozzolans. In Brazil, for example, one of the wastes generated from agro-industrial activities comes from elephant grass that is cultivated as biomass for energy cogeneration. This study evaluated the effect of hot water treatment on the crystalline structure of elephant grass ashes calcinated in two different temperature $\left(700\right.$ and $\left.900^{\circ} \mathrm{C}\right)$. To study the chemical structure and the composition of the ashes the X-ray fluorescence (XRF) and X-ray diffractions (XRD) analyses were carried out. The results achieved in the present work shown that, elephant grass ashes meet the ASTM C-618 standard, for the minimum sum content of the silica $\left(\mathrm{SiO}_{2}\right)$, aluminum $\left(\mathrm{Al}_{2} \mathrm{O}_{3}\right)$ and iron $\left(\mathrm{Fe}_{2} \mathrm{O}_{3}\right)$ oxides, of $50 \%$ to be considered as a pozzolanic material. The presence of an amorphous phase has been detected in all XRD patterns. The ashes calcinated at $700^{\circ} \mathrm{C}$ showed lower crystallinity and the treatment with hot water decreased crystallite size, i.e., the material became more amorphous. On the other hand, the ashes calcinated at $900^{\circ} \mathrm{C}$, less reactive, had a lower content of $\mathrm{K}_{2} \mathrm{O}$. Therefore, the hot water treatment was effective to reduce the potassium content in the ashes. Additionally, it contributed to reduce the crystallite size of silica in the ash calcinated at $700^{\circ} \mathrm{C}$, while the effect is contrary to the ash calcinated at $900^{\circ} \mathrm{C}$.
\end{abstract}

Keywords: Mineral addition, biomass, amorphous formation, potassium leaching, crystallite size.

\section{RESUMO}

Nos últimos anos, os resíduos agroindustriais têm ganhado atenção na comunidade científica, como uma nova fonte de pozolana. No Brasil, por exemplo, um dos resíduos gerados pelas atividades agroindustriais provém do capim-elefante que é cultivado como biomassa para a cogeração de energia. Este estudo avaliou o efeito do tratamento com água quente na estrutura cristalina da cinza de capim elefante calcinada em duas temperaturas diferentes $\left(700\right.$ e $\left.900^{\circ} \mathrm{C}\right)$. Para estudar a estrutura química e a composição das cinzas foram realizadas as análises de fluorescência de raios-X (FRX) e difração de raios-X (DRX). Os resultados obtidos no presente trabalho mostraram que, as cinzas de capim elefante atendem as especificações da norma ASTM C-618, como, o teor mínimo da soma dos óxidos de silício $\left(\mathrm{SiO}_{2}\right)$, de alumínio $\left(\mathrm{Al}_{2} \mathrm{O}_{3}\right)$ e de ferro $\left(\mathrm{Fe}_{2} \mathrm{O}_{3}\right)$, de $50 \%$, para ser considerado como um material pozolânico. A presença de uma fase amorfa foi identificada em todos os difratogramas. As cinzas calcinadas a $700^{\circ} \mathrm{C}$ apresentaram menor cristalinidade e o tratamento com 
água quente diminuiu o tamanho de cristalito, ou seja, o material tornou-se mais amorfo. Entretanto, as cinzas calcinadas a $900^{\circ} \mathrm{C}$, apesar de possuir menor teor de $\mathrm{K}_{2} \mathrm{O}$, apresentaram maior cristalinidade, sendo menos reativas. Portanto, o tratamento com água quente foi efetivo para a redução do teor de potássio nas cinzas. Como também, contribuiu para reduzir o tamanho de cristalito da sílica das cinzas calcinadas a $700^{\circ} \mathrm{C}$, no entanto, o efeito foi contrário para as cinzas calcinadas a $900^{\circ} \mathrm{C}$.

Palavras-chave: Adição mineral, biomassa, formação de amorfos, lixiviação de potássio, tamanho de cristalito.

\section{INTRODUCTION}

Biomass is defined as any organic material derived from plants and animals, which includes phytomass, zoomass, such as wood, crops, seaweed, material left over from agricultural and forestry processes, and organic industrial, human and animal waste [1]. Biomass is a clean energy renewable source which provides environmental and economic benefits [2,3].

The elephant grass has been investigated as a new source of biomass [1,4]. Elephant grass is a plant species native from Africa with high growth rates, reaching 40 tons of dry biomass per hectare per year [1]. The interest based on elephant grass (Pennisetum purpureum) as a biomass energy source is due to its ability to accumulate dry matter with high percentage of fiber similar to sugarcane [5].

Although elephant grass commonly has been used in animal feed, this raw material has shown great potential in other industrial applications, such as second-generation ethanol production [6], biogas, bio-oil and charcoal fabrication [1,7], and energy generation, through the production of thermal energy [8]. Additionally, there are several studies using ashes from elephant grass as a pozzolanic material to use as a mineral addition in cementitious material [9-12].

According to Hewlett [13] pozzolan denotes all inorganic materials, including natural or non-natural, silica or silicoaluminum, which when mixed with calcium hydroxide (lime) or materials that release calcium hydroxide (e.g. cement) harden in the presence of water. Pozzolans present two phases, the active, that is able to react with lime, being rich in silica; and the inert, insensitive or non-lime sensitive.

Simulations performed by Fairbairn et al. [14] demonstrated that the mineral addition in cement-based composites could result in environmental benefits. Therefore, the use of mineral addition perfectly fits into Clean Development Mechanisms projects.

Some factors have a direct influence on the reactivity of the ceramic materials, e.g., final temperature, burning time, heating rate and isotherms along the path or at the end of the sintering/calcination process [15]. The control of the calcination variables is an important parameter to produce the desired phases in the resulting material [16] and, in the case of the ashes, greater amount of amorphous $\mathrm{SiO}_{2}$, i.e., more reactive to act combined with Portland cement [16-19].

The literature shows that elephant grass biomass has already been calcinated at different temperatures, within the range of $500^{\circ} \mathrm{C}$ to $900^{\circ} \mathrm{C}$ [12]; the increase in temperature provided an increase in density and a decrease in surface area [20]. The authors could also observe that the index of pozzolanic activity among the ashes calcinated at 500, 700, 800 and $900^{\circ} \mathrm{C}$ ranging from 93 to $98 \%$. However, the burning at $600^{\circ} \mathrm{C}$ was the one with the best pozzolanic activity of $108 \%$ [12].

On the other hand, the elephant grass ash contains a large amount of potassium oxide, as presented by Nakanishi et al. [9] and Cordeiro and Sales [12], requiring a pre-treatment with hot $\mathrm{HCl}$ solution for the extraction of potassium oxide excess by reduction of $\mathrm{K}_{2} \mathrm{O}$ to $\mathrm{KOH}$ and further neutralization process using $\mathrm{HCl}$, as indicated by Equations 1 and 2. [21].

$$
\begin{aligned}
& \mathrm{K}_{2} \mathrm{O}_{(s)}+\mathrm{H}_{2} \mathrm{O}_{(l)} \rightarrow 2 \mathrm{KOH}_{(\text {aqueous })} \\
& \mathrm{KOH}_{(\text {(qqueous) }}+\mathrm{HCl}_{(\text {aqueous })} \rightarrow 2 \mathrm{KCl}_{(s)}+\mathrm{H}_{2} \mathrm{O}_{(l)}
\end{aligned}
$$

The alkali ions such as $\mathrm{K}$ and $\mathrm{Na}$ in pozzolanic materials must be avoided based on two reasons: $\mathrm{A}$ ) The alkali ions in the solution can increase the $\mathrm{pH}$ of the reaction, decreasing the solubility of calcium ions and therefore enhancing the solubility of silicates, which are structures that acts like a filler, decreasing the cement strength [22]; B) The alkaline ions can cause the alkali-aggregate reaction in the cement matrix [23]. 
The alkali ions with moisture form a gel structure that results in crack propagation and a consequently damaging the cement matrix [13]. Therefore, the reduction of potassium ions $\left(\mathrm{K}_{2} \mathrm{O}\right)$ in the reaction medium makes the use of ashes most attractive as pozzolanic materials. The amount of potassium and other chemical elements varies depending on the species, type of soil cultivated, crop age, climate, among other factors (e.g., fertilize usage). However, after the utilization of this cleaning process, the residual chloride solution is a problem to handle.

One way to solve these problems is to look for other alternatives, focusing especially on hot water solution [24]. It is well known that the solubility of chemical species, especially alkalis, increases substantially with temperature, so the effect of hot water can be a viable alternative to the $\mathrm{HCl}$ treatment. Complementarily, the increase in the burning temperature will favor the decrease of the loss on ignition (LOI) value as, if the temperature exceeds the melting point of potassium, which is $740^{\circ} \mathrm{C}$ [25], probably there will be a decrease in its concentration.

The pozzolanic activity evaluation of the ashes is usually done using measurements of electrical conductivity in calcium hydroxide / ash systems [26]. The reaction is performed in aqueous medium, where the reaction of calcium hydroxide $(\mathrm{CH})$ and pozzolan varies according to the following factors: nature of the active phases of pozzolan (amorphous $\mathrm{SiO}_{2}$ ), $\mathrm{CH}$-pozzolan ratio in the mixture, release rate of pozzolan from the cluster and temperature [27]

The electrical conductivity measurement aims at the interaction between amorphous silicon oxide ions and calcium, to simulate the process that occurs with the presence of pozzolan in the cement [28]. However, the evolution of the amorphization process of silica during burning is not known, which can generate more crystalline than amorphous material, during the process of nucleation and growth of the particles [29].

This study aimed to evaluate the effect of hot water treatment in the change of crystalline structure of elephant grass ashes calcinated in two different temperatures: 700 and $900^{\circ} \mathrm{C}$.

\section{MATERIAL AND METHODS}

\subsection{Elephant grass processing}

The elephant grass Napier variety (Pennisetum purpureum) was collected from the cultivation at the campus

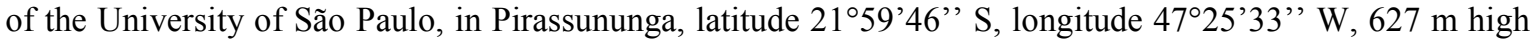
above sea level, and Tropical Climate of Altitude (Cwa), Brazil. The material was cut with 150 days age. Subsequently, the material was dried in an oven at $60^{\circ} \mathrm{C}$ for $72 \mathrm{~h}$ and then a milling process was carried out. The elephant grass ash (EGA) was produced in an electric furnace with a $10^{\circ} \mathrm{C} / \mathrm{min}$ heating rate, first at $400^{\circ} \mathrm{C}$ for $20 \mathrm{~min}$ and then at $700^{\circ} \mathrm{C}$ (EG700A) or at $900^{\circ} \mathrm{C}$ (EG900A) for $60 \mathrm{~min}$ (Fig. 1). Cooling was carried out naturally with the electric furnace door closed, with a cooling rate of approximately $1.0^{\circ} \mathrm{C} / \mathrm{min}$.

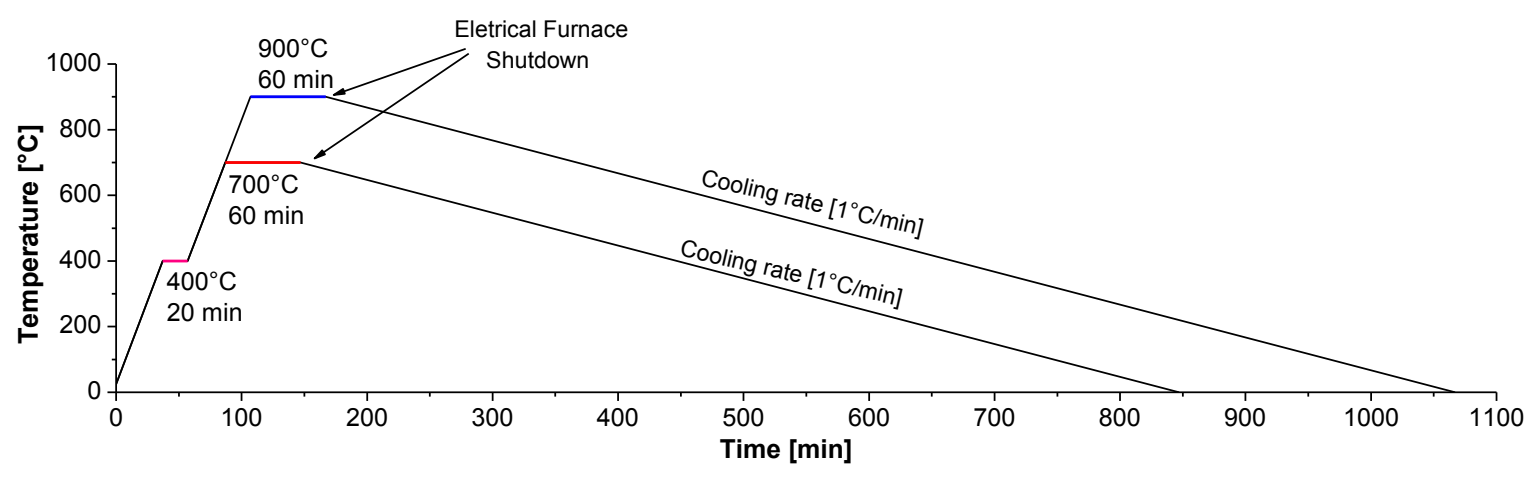

Figure 1: Graphic of burning process, representation of temperature $\mathrm{x}$ time.

Part of the calcinated ash, at $700^{\circ} \mathrm{C}(\mathrm{EG} 700 \mathrm{~B})$ and $900^{\circ} \mathrm{C}(\mathrm{EG} 900 \mathrm{~B})$, was treated with hot water for the extraction of alkali ions, especially potassium, according to Nakanishi et al. [24]. The cleaning procedure was constituted by the dispersion of $600 \mathrm{~g}$ of ashes per liter of water at $70^{\circ} \mathrm{C}$ during 30 min under mixing [24]. The four different conditions of treated ashes are summarized in Table 1. 
Table 1: Elephant grass ashes treatment.

\begin{tabular}{lll}
\hline Ashes & Burning temperature $\left({ }^{\circ} \mathrm{C}\right)$ & Hot water treatment \\
\hline EG700A & 700 & No \\
EG700B & 700 & Yes \\
EG900A & 900 & No \\
EG900B & 900 & Yes \\
\hline
\end{tabular}

\subsection{Elephant grass ash characterization}

Chemical characterization of the ashes was carried out by X-ray fluorescence (XRF), with the X Axios Advanced PANalytical apparatus. The mineralogical characterization was carried out by X-ray diffraction analysis technique (XRD), in order to study the crystalline and amorphous phases of the ashes, and to determine the crystallite size of samples. The equipment used was the AXS diffractometer Analytical X-Ray Systems (Siemens, D5005) operated at $1600 \mathrm{~W}, 40 \mathrm{kV}$ x $40 \mathrm{~mA}, \mathrm{Cu}-\mathrm{K} \alpha$ radiation, $1.54056 \AA$ wavelength. The results of the diffractograms were taken in the range from 10 to $70^{\circ}(2 \theta)$, with a rate of $2^{\circ} / \mathrm{min}$. The crystallite size of the plane structure represented by the peak 101 relative to quartz was determined by the equation of Scherrer, described by Landford and Wilson [30], according to equation 3:

$$
D=\frac{K \lambda}{\beta \cos \theta}
$$

Where $\mathrm{D}$ is the size perpendicular to the plane of the structure represented by the peak (101), $\mathrm{K}=0.9$, is a constant related to the shape of the crystals and the reflectance indices of the plane (101), $\lambda$ is the wavelength of the incident beam in the diffraction experiment, $\beta$ is the peak width at half maximum (pwhm) in radians and $\theta$ is the position of the peak (half of the value $2 \theta$ ).

X-ray diffraction patterns were analyzed and compared to the data obtained by International Centre for Diffraction Data and Panalytical Inorganic Crystal Structure Database.

\section{RESULTS AND DISCUSSIONS}

\subsection{Elephant grass ashes composition}

Based on ASTM C-618 [31] methodology, the elephant grass ashes can be classified as class C. This class includes fly ash and waste biomass, in addition it must present pozzolanic properties. The minimum amount recommended for the total of $\mathrm{SiO}_{2}, \mathrm{Al}_{2} \mathrm{O}_{3}$ and $\mathrm{Fe}_{2} \mathrm{O}_{3}$ to classify a mineral addition as a potential pozzolanic material is $50 \%$. Further, the normative document suggests the maximum admissible values of sulfur trioxide $\left(\mathrm{SO}_{3}\right)$ of $5 \%$ and loss on ignition of $6 \%$. Table 2 presents the chemical composition of the ashes. In addition, it is worth noting that beyond to the aforementioned requirements it would be necessary to evaluate the physical properties, e.g. strength activity index.

Following the evaluation proposed in the ASTM C-618 Standard [31], the total amount of silicon dioxide $\left(\mathrm{SiO}_{2}\right)$, aluminum oxide $\left(\mathrm{Al}_{2} \mathrm{O}_{3}\right)$ and iron oxide $\left(\mathrm{Fe}_{2} \mathrm{O} 3\right)$ was equivalent to $53.1 \%, 60.8 \%, 71.6 \%$ and $77.0 \%$ for EG700A, EG700B, EG900A and EG900B respectively. The values of sulfur trioxide $\left(\mathrm{SO}_{3}\right)$ and loss on ignition were less than recommended by the referred Standards. 
Table 2: Chemical composition of ashes by XRF technique.

\begin{tabular}{lllllllllllll}
\hline \multicolumn{1}{c}{ Oxides (\% by mass) } \\
\cline { 2 - 14 } & $\mathrm{Na}_{2} \mathrm{O}$ & $\mathrm{MgO}$ & $\mathrm{Al}_{2} \mathrm{O}_{3}$ & $\mathrm{SiO}_{2}$ & $\mathrm{P}_{2} \mathrm{O}_{5}$ & $\mathrm{SO}_{3}$ & $\mathrm{Cl}$ & $\mathrm{K}_{2} \mathrm{O}$ & $\mathrm{CaO}$ & $\mathrm{MnO}$ & $\mathrm{Fe}_{2} \mathrm{O}_{3}$ & $\mathrm{LOI}$ \\
\hline EG700A & 0.18 & 3.98 & 0.60 & 51.80 & 4.91 & 2.82 & 2.77 & 22.00 & 5.68 & 0.08 & 0.73 & 4.22 \\
EG700B & 0.16 & 4.71 & 0.72 & 59.30 & 5.37 & 0.64 & 0.76 & 17.70 & 6.72 & 0.10 & 0.82 & 2.76 \\
EG900A & 0.18 & 4.87 & 0.52 & 70.20 & 3.44 & 3.61 & 0.19 & 9.06 & 5.30 & 0.08 & 0.85 & 1.45 \\
EG900B & 0.19 & 5.34 & 0.61 & 75.60 & 3.73 & 0.57 & 0.17 & 7.26 & 5.48 & 0.08 & 0.80 & $<$ \\
\hline
\end{tabular}

$<$ traces (minor than $0.01 \%$ ); LOI $=$ loss of ignition at $1000^{\circ} \mathrm{C}$.

The increase in the calcination temperature resulted in a reduction of the organic compounds present in the ash, as observed by the decreasing of the $\mathrm{K}_{2} \mathrm{O}$ and LOI content, consequently there was an increase in the silica oxide content, which was already expected. Cordeiro and Sales [12] also observed this behavior with elephant grass ashes. These studies showed that the high content of potassium oxide was reduced by increasing the calcination temperature, which is partly due to the calcination temperature above the potassium melting point, e.g., $740^{\circ} \mathrm{C}[25]$.

However, the ashes present a high percentage of potassium $\left(\mathrm{K}_{2} \mathrm{O}\right)$ in its chemical composition, what is potentially damaging to application as a mineral addition in cement-based materials, justifying the hot water treatment to extract the excess of alkali content [24]. It can be seen an increase in the content of $\mathrm{SiO}_{2}, \mathrm{MgO}$ and $\mathrm{Al}_{2} \mathrm{O}_{3}$, and a decrease in the content of $\mathrm{K}_{2} \mathrm{O}, \mathrm{Cl}, \mathrm{SO}_{3}$ and loss of ignition (LOI) in the treated ashes in both calcination temperatures (Table 2). The content of potassium oxide was reduced by approximately $20 \%$ in both ashes (EG700B and EG900B). The hot water treatment showed a reduction in potassium levels. According to Table 2 , the ashes calcinated at $900^{\circ} \mathrm{C}$ present a greater percentage of silica than the ash calcinated at $700^{\circ} \mathrm{C}$, however, only the $\mathrm{SiO}_{2}$ amorphous is reactive like pozzolana in cement-based binder.

\subsection{Elephant grass ashes characterization by X-Ray diffraction analysis}

Figure 2 illustrates normalized XRD patterns of the ashes calcinated at $700^{\circ} \mathrm{C}$ and $900^{\circ} \mathrm{C}$, without and with hot water treatment. The presence of a halo of Bragg angles $(2 \theta)$ between $20^{\circ}$ to $35^{\circ}$ has been detected in all XRD patterns; it indicated the presence of an amorphous phase. On the basis of this, the XRD pattern of the EG700 ash the amorphous halo was more highlighted. According to Frias et al. [32], the greater presence of amorphous phase potentially presents a more reactive ash to be used as pozzolanic material. The XRD data showed an increase of crystalline phase for the ash calcinated at $900^{\circ} \mathrm{C}$ becoming this ash less reactive. The presence of quartz $\left(\mathrm{SiO}_{2}\right)$ crystalline phases were characterized by using the JCPDS pattern number 46-1045.

It was noticed a bigger amorphous halo for the treated EG700B ash. This behavior was not observed at high temperatures. The absence of potassium crystalline phases, as sylvite $(\mathrm{KCl})$ and arcanite $\left(\mathrm{K}_{2} \mathrm{SO}_{4}\right)$ in treated ashes indicated the solubility of these phases in hot water. Therefore, it is possible notice that treatment employed in this study was the efficient to extract the potassium of the elephant grass ashes. 

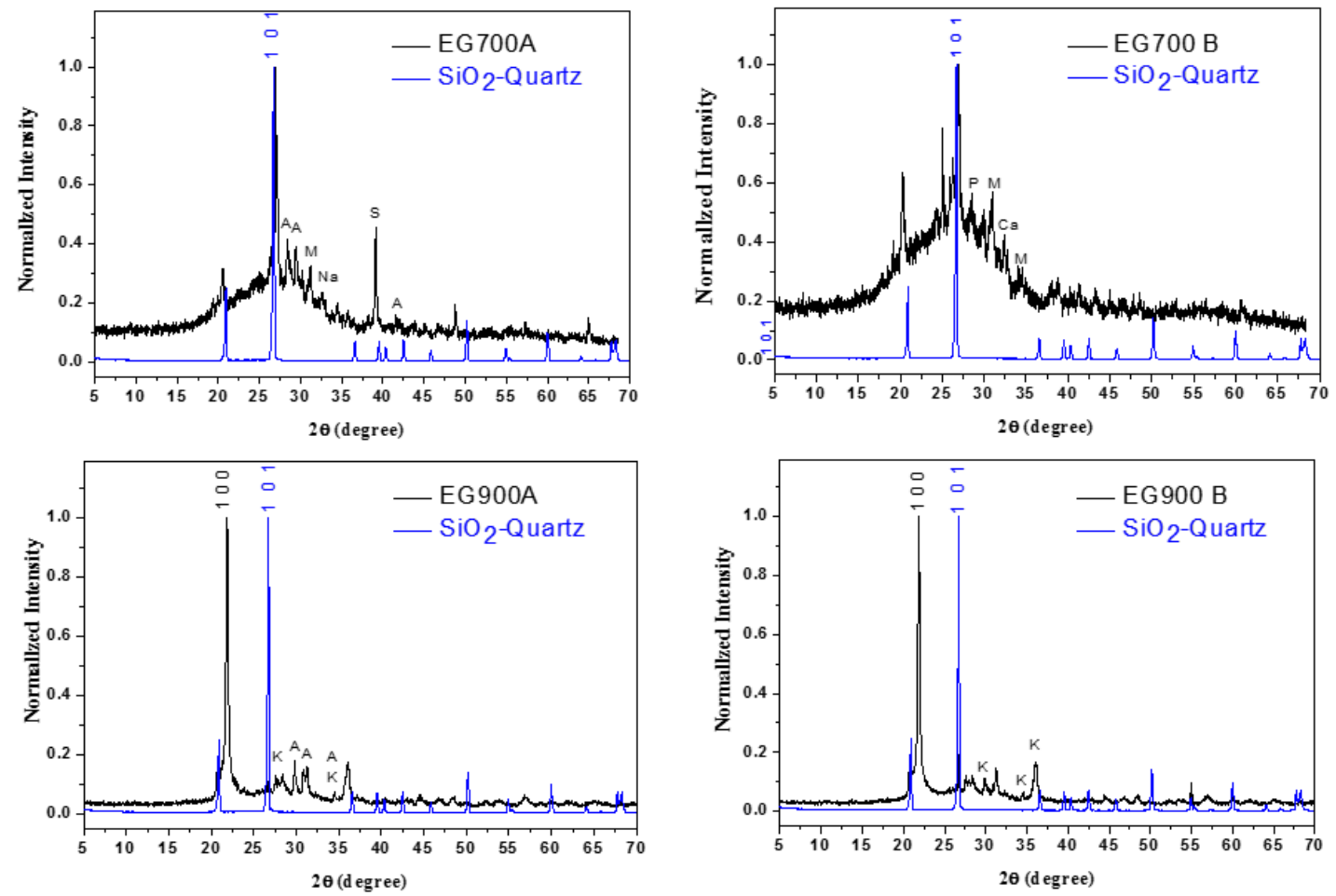

Figure 2: XRD normalized pattern of the EG700A, EG700B, EG900A and EG900B ashes. The blue curve represents an experimental calculation of the crystalline quatz pattern. Crystalline phases: $\mathrm{S}$ - Sylvite $(\mathrm{KCl})$. A - Arcanite $\left(\mathrm{K}_{2} \mathrm{SO}_{4}\right)$; $\mathrm{M}$ Magnesite $\left(\mathrm{MgCO}_{3}\right)$; $\mathrm{Na}$ - Sodium Magnesium Phosphate $\left(\mathrm{NaMgPO}_{4}\right)$; $\mathrm{Ca}$ - Calcium oxide $(\mathrm{CaO} 4)$; $\mathrm{P}$ - Potassium Magnesium Phosphate $\left(\mathrm{KMgPO}_{4}\right)$; K - Potassium Calcium Magnesium Phosphate $\left(\mathrm{CaMgK}\left(\mathrm{PO}_{4}\right)_{7}\right)$.

\subsection{Phase change of $\mathrm{SiO}_{2}$}

Based on the XRD results, it was observed that the increase of the burning temperature from $700^{\circ} \mathrm{C}$ to $900^{\circ} \mathrm{C}$ resulted in an increase in the direction of the plane (100) of the quartz. As seen in Figure 2, a change in the amorphous phase of the ashes was noticed by the variation in the burning temperature. In theory, trigonal quartz ( $\alpha$-quartz) has been transformed into hexagonal quartz ( $\beta$-quartz), when heated to $573^{\circ} \mathrm{C}-870^{\circ} \mathrm{C}$ under pressure control and with presence of impurities in the crystal lattice, such as sulfur, iron and magnesium [33].

The phase transformation occurs by the increase of the surface energy and alteration in the structural arrangements of the tetrahedron $\left[\mathrm{SiO}_{2}\right]$ [34]. During this phase transformation, the $\mathrm{Si}-\mathrm{O}$ arrangements change from three-dimensional mosaic to mix setup, prevailing the structural rearrangement (twist), until the final transition [35], when other crystallographic structure are formed by break down of the corner-sharing $\mathrm{SiO}_{4}$ tetrahedrons [36].

The $\beta$-tridymite phase has been obtained at $870^{\circ} \mathrm{C}$, depending on the amount of impurities present in the crystal lattice [33].

The changes in the crystalline structure lead to modifications in the specific density of the quartz. It happens due to the increase of the vibrations of the atoms in the crystalline network, making the structures with a more open angle of connection (Si-O-Si), i.e., closer to $109^{\circ}$ [37], being structure of the elephant grass ash silicon more crystalline.

\subsection{Reflections of calcination temperature and hot water treatment on crystalline structure}

Crystalline phases have been quantified by Scherrer equation and were calculated using the crystallite diameter of crystalline quartz. Among all polymorphs of silica, quartz is the only stable at ambient conditions, as the other types of silica polymorphs are stable when subjected to elevated temperature and pressure, and rarely formed at low temperatures and pressures [33, 38]. 
It is seen that for the EG700A ash the crystallite size of the quartz was lower than those observed for the EG900A ash (Table 3). Therefore, the elephant grass ash produced at $700^{\circ} \mathrm{C}$ presented the greatest potential as a pozzolanic material. The obtained results corroborate with a study conducted by Villar-Cociña et al [39], the authors suggest that the more amorphous $\mathrm{SiO}_{2}$ present the higher reactivity when used as a mineral addition in conjunction with Portland cement. The crystallite size confirms the effectiveness of the treatment with hot water; the treatment, becoming the quartz of EG700B ash less crystalline i.e., the crystallite size became smaller, as presented in Table 3.

Table 3: The calculation of the crystallite size by Scherrer equation.

\begin{tabular}{lc}
\hline Sample & Crystallite size $(\AA) *$ \\
$\mathrm{SiO}_{2}$ & 102.59 \\
EG700A & 81.69 \\
EG700B & 76.41 \\
EG900A & 200.02 \\
EG900B & 368.35
\end{tabular}

*Experimental measurement obtained from the XRD normalized pattern by Scherrer calculation

The smaller crystallite size in the EG700B after the treatment confirms the greater amorphous halo presence observed in the DRX patterns (Figure 2). Probably, when the hot water treatment was carried out, part of the potassium present in the coordination sphere of the Si-O-Si cluster is removed due to the increase of the value of the dissociation constant (kps) [40].

The increase in the burning temperature $\left(900^{\circ} \mathrm{C}\right)$ also increases the dissociation constant (kps) but promotes an increase in the plane 100 of the quartz, raising the crystallinity, thus the hot water treatment become ineffective for the removal of ions in coordination sphere of potassium, which requires much energy because the stability of the structure [41].

In view of all, the treatment with hot water in EG700 helped leaving the less crystalline quartz, i.e., a less stable structural rearrangement, which associated with potassium loss allows to the elephant grass ash a great potential as pozzolanic material.

\section{CONCLUSIONS}

According to these first experimental results, the higher alkali oxide percentage and a more amorphous nature was shown for the elephant grass calcinated at $700^{\circ} \mathrm{C}$.

Hot water treatment was partially efficient to extract excessive amount of alkalis from the ashes. However, at both temperatures there is a decrease of potassium content of approximately $20 \%$, with the best results for ash EG900B $(<8 \%)$, that was in accordance with the limit allowed for application in cement matrices. However, the amorphous phase was less representative for ashes calcinated at $900^{\circ} \mathrm{C}$.

The treatment by hot water also contributed to reduce the crystallite size of silica in the ash calcinated at $700^{\circ} \mathrm{C}$, while the effect is contrary to the ash EG900B.

Therefore, a combined burn at $700^{\circ} \mathrm{C}$ and hot water treatment generates ashes with improved properties as mineral addition and higher pozzolanic activity in comparison with the untreated counterpart. At this stage, these ashes could be appropriate for application in cement-based materials with low amount of mineral addition or with low risk of alkali-aggregate reaction. Additional research is needed to further improve the efficiency of the methodology as discussed above, including higher water temperatures and longer leaching time, mainly, in order to achieve a better extraction efficiency of $\mathrm{K}_{2} \mathrm{O}$. In addition, it is worth noting that beyond to the aforementioned requirements it would be necessary to evaluate the physical properties, e.g. strength activity index. 


\section{ACKNOWLEDGMENTS}

The authors are grateful to FAPESP (Grants 2011/16842-5, 2016/07372-9, 2013/23810-8 and 2012/51467-3), to CNPq (Grants 150384/2016-5, 312151/2016-0 and 306386/2013-5) and to the Framework Agreement of Collaboration between IETcc/CSIC (Spain) and FZEA/USP (Brazil) (Grant: 2013040043). Also, to i-LINK Program between CSIC (Grant: i-Link 0675-2013), and FAPESP (Grant 2013/50790-8) for their financial support.

\section{BIBLIOGRAPHY}

[1] STREZOV, V., EVANS, T.J., HAYMAN, C., "Thermal conversion of elephant grass (Pennisetum Purpureum Schum) to bio-gas, bio-oil and charcoal", Bioresource Technology. v.99, n.17, pp.8394-8399, Nov. 2008.

[2] ABBASI, T., ABBASI, S.A., "Biomass energy and the environmental impacts associated with its production and utilization”, Renewable and Sustainable Energy Reviews, v.14, n.3, pp.919-937, April 2010.

[3] SAIDUR, R., ABDELAZIZ, E.A., DEMIRBAS, A., et al., "A review on biomass as a fuel for boilers", Renewable and Sustainable Energy Reviews, v.15, n.5, pp.2262-2289, Jun. 2011.

[4] BRITO, C.M.A., "Biomass a great option for complementary energy" (in Portuguese), Smart E-energy, n.2, pp.23-28. Jul/Aug. 2010.

[5] QUESADA, D.M., BODDEY, R.M., MASSENA REIS, V., et al., Qualitative parameters of elephant grass genotypes (Pennisetum purpureum Schum.) studied for the production of energy through Biomass (in Portuguese), Circular Técnica 8, Seropédica, RJ, 2004.

[6] MENEGOL, D., FONTANA, R.C., DILLON, A.J.P., et al., "Second-generation ethanol production from elephant grass at high total solids", Bioresource Technology, v.211, pp.280-190, Jul. 2016.

[7] FONTOURA, C.F., BRANDÃO, L.E., GOMES, L.L., "Elephant grass biorefineries: towards a cleaner Brazilian energy matrix?”, Journal of Cleaner Production, v.96, pp.85-93, Jun. 2015.

[8] ROCHA, J.R.A.S.C., MACHADO, J.C., CARNEIRO, P.C.S., et al., "Elephant grass ecotypes for bioenergy production via direct combustion of biomass", Industrial Crops and Products, v.95, pp.27-32, Jan. 2017.

[9] NAKANISHI, E.Y., FRÍAS, M., MARTÍNEZ-RAMÍREZ, S., et al., "Characterization and properties of elephant grass ashes as supplementary cementing material in pozzolan/Ca( $\mathrm{OH})_{2}$ pastes", Construction and Building Materials, v.73, pp.391-398, Dec. 2014.

[10] NAKANISHI, E.Y., FRÍAS, M., SANTOS, S.F., et al., "Investigating the possible usage of elephant grass ash to manufacture the eco-friendly binary cements", Journal of Cleaner Production, v.116, pp.236243, Mar. 2016.

[11] CORDEIRO, G.C., SALES, C.P., "Pozzolanic activity of elephant grass ash and its influence on the mechanical properties of concrete", Cement and Concrete Composites, v.55, pp.331-336, Jan. 2015.

[12] CORDEIRO, G.C., SALES, C.P., "Influence of calcining temperature on the pozzolanic characteristics of elephant grass ash", Cement and Concrete Composites, v.73, pp.98-104, Oct. 2016.

[13] HEWLETT, P.C., Lea's Chemistry of Cement and Concrete, 4 ed., London, Butterworth-Heinemann, 2004.

[14] FAIRBAIRN, E.M.R., AMERICANO, B.B., CORDEIRO, G.C., et al., "Cement replacement by sugar cane bagasse ash: $\mathrm{CO}_{2}$ emissions reduction and potential for carbon credits", Journal of Environmental Management, v.91, n.9, pp.1864-1871, Sept. 2010.

[15] RAHAMAN, M.N., Ceramic process and sintering, 2 ed., New York, Marcel Dekker, Inc., 2003.

[16] LEE, B.I., KOMARNENI, S., Chemical Processing of Ceramics, 2 ed., London, Taylor \& Francis Group, LLC., 2005.

[17] WANG, H., GILLOTT, J.E., "Mechanism of alkali-silica reaction and the significance of calcium hydroxide", Cement and Concrete Research, v.21, n.4, pp.647-654, Jul. 1991.

[18] LANG, S.L., Sintering Densification, Grain Growth and Microstructure, 1 ed., Amsterdam, Butterworth-Heinemann, 2004.

[19] SOARES, M.M.S., POGGIALI, F.S.J., BEZERRA, A.C.S., et al., "The effect of calcination conditions on the physical and chemical characteristics of sugar cane bagasse ash", Rem: Revista Escola de Minas, v.67, n.1, pp.33-39, Jan/Mar 2014. 
[20] FRÍAS, M., RODRÍGUES, O., SÁNCHEZ ROJAS, M.I., "Paper sludge, an environmentally sound alternative source of MK-based cementitious materials. A review", Construction and Building Materials, v.74, pp.37-48, Jan. 2015.

[21] SKOOG, D.A., WEST, D.M., HOLLER, F.J., et al., Analytical Chemistry an Introduction, 7 ed., South Melbourne, Brooks/Cole, Vic, 2000.

[22] LEE, F.C., BANDA, H.M., GLASSER, F.P., "Substitution of Na, Fe and Si in tricalcium aluminate and the polymorphism of solid solutions", Cement and Concrete Research, v.12, n.2, pp.237-246, Mar. 1982.

[23] FREIRE, W.J., BERALDO, A.L., Technology and Alternative Construction Materials (In portuguese), 1 ed., Campinas, Unicamp, 2003.

[24] NAKANISHI, E.Y., VILLAR-COCIÑA, E., SANTOS, S.F., et al., "Thermal and chemical treatments for removal of alkali oxides of elephant grass ashes" (in Portuguese), Química Nova, v.37, n.5, pp.766-769, Apr. 2014

[25] BAYSINGER, G., BERGER, L.L., GOLDBERG, R.N., et al., Handbook of Chemistry and Physics, 90 ed., Boca Raton, FL, CRC Press/Taylor and Francis, 2009.

[26] FRÍAS, M., VILLAR-COCIÑA, E., SAVASTANO JR, H., "Brazilian sugar cane bagasse ashes from the cogeneration industry as active pozzolans for cement manufacture", Cement and Concrete Composites, v.33, n.4, pp.490-496, Apr. 2011.

[27] CORDEIRO, G.C., TOLEDO FILHO, R.D., FAIRBAIRN, E.M.R., "Effect of calcination temperature on the pozzolanic activity of sugar cane bagasse ash", Construction and Building Materials, v.23, n.10, pp.3301-3303, Oct. 2009.

[28] SATA, V., TANGPAGASIT, J., JATURAPITAKKUL, C., et al., "Effect of W/B ratios on pozzolanic reaction of biomass ashes in Portland cement matrix", Cement and Concrete Composites, v.34, n.1, pp.94100, Jan. 2012.

[29] MERSMANN, A., Crystallization Technology Handbook, 2 ed., New York, Marcel Dekker, Inc., 2001.

[30] LANGFORD, J.I., WILSON, A.J.C., "Scherrer after sixty years: A survey and some new results in the determination of crystallite size", Journal of Applied Crystallography, v.11, pp.102-113, 1978.

[31] AMERICAN SOCIETY FOR TESTING AND MATERIALS (ASTM): Standard Specification for Coal Fly Ash and Raw or Calcined Natural Pozzolan for Use in Concrete, ASTM C618, United States, 2012.

[32] FRÍAS, M., SAVASTANO JR, H., VILLAR-COCIÑA, E., et al., "Characterization and properties of blended cement matrices containing activated bamboo leaf wastes", Cement and Concrete Composites, v.34, n.9, pp.1019-1023, Oct. 2012.

[33] KEEN, D.A., DOVE, M.T., "Local structures of amorphous and crystalline phases of silica, $\mathrm{SiO}_{2}$, by neutron total scattering", Journal of Physics: Condensed Matter, v.11, n.47, pp.9263-9273, 1999.

[34] FREUND, H.J., "Controlling Silica in Its Crystalline and Amorphous States: A Problem in Surface Science", Accounts of chemical research, v.50, n.3, pp.446-449, Mar. 2017.

[35] BÜCHNER, C., WANG, Z., BURSON, K.M., et al., "A Large-Area Transferable Wide Band Gap 2D Silicon Dioxide Layer”, A C S Nano, v.10, n.8, pp.7982-7989, Jul. 2016.

[36] BINDER, K., KOB, W., Glassy material and disordered solids: An introduction to their statistical mechanics, Revised ed., Sigapore, World Scientific Publishing Company, 2005.

[37] HATCH, D.M., BJORKSTAM, S.G., "The $\alpha-\beta$ phase transition in AlPO4 cristobalite: Symmetry analysis, domain structure and transition dynamics", Physics and Chemistry of Minerals, v.21, n.1, pp.67-77, May 1994.

[38] POMPONIO, A.D., CONTINENZA, A., PASSACANTANDO, M., et al., "Electronic properties of crystalline and amorphous $\mathrm{SiO}_{2}$ investigated via all-electron calculations and photoemission spectroscopy", Solid State Communications, v.95, n.5, pp.313-317, Aug. 1995.

[39] VILLAR-COCIÑA, E., MORALES, E.V., SANTOS, S.F., et al., "Pozzolanic behavior of bamboo leaf ash: characterization and determination of the kinetic parameters", Cement and Concrete Composites, v.33, n.1, pp.68-73, Jan. 2011.

[40] CHRISTIAN, G.D., Analytical Chemistry, 7 ed., Washington, John Wiley and Sons Inc., 2004. 
[41] DAPIAGGI, M., PAGLIARI, L., PAVESE, A., et al., "The formation of silica high temperature polymorphs from quartz: Influence of grain size and mineralising agents", Journal of the European Ceramic Society, v.35, n.16, pp.4547-4555, Dec. 2015. 